\title{
Moderators in the relationship between intention to continue using social networks and its causes
}

\author{
Alberto Un Jan, Doctor ${ }^{1}$, , Vilma Un Jan, B.S., ${ }^{2}$ and Vilma Contreras, B.S. ${ }^{1}$ \\ ${ }^{1}$ Universidad Nacional de Ingeniería, Perú, eun-jan@uni.edu.pe * Corresponding author \\ ${ }^{2}$ Florida Gulf Coast University, U.S., vilmaunjan@gmail.com \\ ${ }^{3}$ Universidad Nacional de Ingeniería, Perú, vcontreras467@gmail.com
}

\begin{abstract}
The aim of this research is to study privacy restrictiveness and site experience as moderators of the relationship between trusting beliefs and usage continuance intention, and between habit and usage continuance intention. The research defines social networks (SNW) and proposes that habit and trusting beliefs affect usage continuance intention in SNW. The research question is "What is the influence of privacy restrictiveness and site experience as moderators of the variables that influence usage continuance intention of social networks?" The survey asks about privacy restrictiveness and site experience to show they moderate the effects of trusting beliefs and habit on $S N W$ usage continuance intention. The research team ran the survey in a university environment, including public and private universities. The study finds that usage continuance intention influences the use of SNW. Variables that affect this intention are trusting beliefs, habit and attitude toward using the SNW. Privacy restrictiveness and site experience moderate the relationship between trusting beliefs and usage continuance intention, and between habit and usage continuance intention. To improve the real use of $S N W$, universities must work on these variables.

Keywords- Usage continuance intention; attitude toward using the social network; trusting beliefs; habit; privacy restrictiveness; site experience.
\end{abstract}

\section{INTRODUCTION}

Internet is an information technology environment that serves as a platform for communication channels, affecting ways of life. Internet of things, for example, connects more devices every day, devices with or without processors. Search engines find millions of web pages in less than a second. Online sales, together with cheaper rates in physical delivery, and money transfer through bank and credit card transactions, are the success factors for many businesses. Social networks (SNW) bring people together for social, academic or business purposes, among others. In this context, social networks are able to bring together the previous concepts of communication, searching for persons and businesses. The use of mobile devices, such

Digital Object Identifier (DOI):

http://dx.doi.org/10.18687/LACCEI2019.1.1.219

ISBN: 978-0-9993443-6-1 ISSN: 2414-6390 as intelligent cell phones, tablets and laptops, and the availability of broadband wireless signals, improve the use of technology at all ages, in any place, for multiple applications.

\section{A.}

Social networks $(S N W)$

and munication technology, this research studies social networks. SNW appeared since the beginning of the $21^{\text {st }}$ century; well - known examples are LinkedIn, Myspace, Facebook, Twitter or Instagram. Through SNW people may build their profile and control the visibility of it by others, by building also connections among selected persons. Social network sites are online settings that allow users to register and connect to each other to communicate or share resources and have a primary focus on social interpersonal communication [1]. Social networks have become a communication platform where different users with a personalized user profile interact and share information with each other [2]. In SNW people create, share, and exchange information and ideas [3]. SNW are a new form of virtual community [4] that have become a popular way for internet users to communicate and interact online [5]. SNW connect people and help them share their interests [6]. The processing speed, broadband in communication, and availability of storage space for data, are fundamental characteristics of information technology that support SNW.

SNW exhibit people's views and ideas, as a social interaction that relies upon personal relationships [7]. Various studies deepen about the influence of social networks on human behavior. Chorley, Whitaker and Allen [8] for example study location-based social networks; these services allow users to record their presence at a location, using smart-phones. Du, Zhang, Li, Yan, Galloway and Lo [9] study the influence of SNW on energy savings. SNW have been increasing in recent years [6], [10], and the amount of data freely available from social networking is also growing [11], being one of its causes the prevalence of mobile devices [12]. In 2018, 3.2

$17^{\text {th }}$ LACCEI International Multi-Conference for Engineering, Education, and Technology: "Industry, Innovation, And Infrastructure for Sustainable Cities and Communities", 24-26 July 2019, Jamaica. 
billion people were active social media users (42.1\% of the total world population) with a growth of $13 \%$ from 2017 to 2018 [13]. The growth of SNW can bring benefits and improvements; however, on the other hand, because discontinuance happens, it is important to understand continuance intention in SNW [14]. The next section will research continuance intention in depth; even more, will also find and study new causes that affect intention.

Another important concept in SNW is electronic word of mouth (e-WOM) [15]. University education, from a business point of view, considers students as customers [16], and makes efforts to retain them, as well as to receive new customers. Students can have an active participation through SNW when they mention, check 'like', or say positive things to others about their university.

B. Intention as a variable that influences the use of SNW

The use of social networks is influenced by intention [14], [17]. Studies have found that usage behavior of online social networking services is determined by behavioral intention, which in turn is determined by individual's attitude, subjective norm and self-efficacy [18]. Zhang [19], in his study about the use of SNW, included behavioral intention as one of three predictors to measure SNW use.

The model by Lankton, McKnight and Thatcher [14] shows various causes for intention. First, based on the theory of reasoned action (TRA) they identify subjective norm and attitude toward using the website. Next, two more variables, trusting beliefs and habit, also influence on intention. Theory of reasoned action (TRA) was proposed by Ajzen and Fishbein [20].

\section{Trusting belief}

Trusting belief is studied with three more detailed concepts: competence, benevolence, and integrity, which are defined by various authors [21], [22], [23]. Trusting intention refers to the willingness of a trustor to depend on the trustee in a given context; trusting beliefs are the beliefs of a trustor in the trustee's competence, benevolence and integrity. Integrity refers to trust, honesty and promise keeping. Benevolence refers to trustee caring and motivation to act in the trustor's interest. Competence is the ability of the trustee to do what the trustor needs; assures that the trustee will protect personal information from hackers. McKnight, Cludhury and Kacmar [24] and Chen, Chien, $\mathrm{Wu}$ and Tsai [25] add predictability and define it as consistency of trusting behavior.
McKnight et al. [24] however, explain that predictability would be more relevant to a model between users and vendors, and therefore they do not include predictability.

D. The research problem

Lankton et al. [14] acknowledge the importance of studying discontinuance in the use of SNW because it can create costs to providers. Even more, in their study, Lankton et al. [14] examine how privacy restrictiveness and site experience moderate the effects of trusting beliefs and habit on website continuance intention. However, Lankton et al. [14] suggest as a limitation of their study, that they used a sample of students from one U.S. university, although the international growth of the SNW. To overcome the limitation, this research will therefore extend the scope to four universities in Perú, two public and two private universities. A good reason to choose universities and to continue this research in the university environment is that universities invest in online environments, and the learning benefits depend on their social integration, adoption and usage [1].

To improve the measurement of privacy restrictiveness and site experience, this research will add items to measure these two constructs. Finally, to broaden the scope of the research, SNW users other than Facebook will be included when identifying the population and preparing the sample. The research problem will be: "What is the influence of 'privacy restrictiveness' and 'site experience' as moderators of the variables that influence 'usage continuance intention' of social networks?"

Lankton et al. [14] in their model, examine privacy restrictiveness and site experience as moderators of trusting beliefs and habit, which in turn affect website continuance intention, and propose the following hypotheses:

H1): Attitude toward using the website will have a positive influence on usage continuance intention. This research will use the construct attitude toward using the $S N W$, instead of website.

H2): Subjective norm will have a positive influence on usage continuance intention.

H3): Trusting beliefs will have a positive influence on usage continuance intention.

H4): Habit will have a positive influence on usage continuance intention.

This research will confirm the mentioned hypotheses. The following hypotheses $\mathrm{H} 5$ to $\mathrm{H} 8$ by Lankton et al. [14] will also be tested to answer the research question, from the moderation point of view:

$17^{\text {th }}$ LACCEI International Multi-Conference for Engineering, Education, and Technology: "Industry, Innovation, And Infrastructure for Sustainable Cities and Communities”, 24-26 July 2019, Jamaica. 
H5): Privacy restrictiveness will moderate the relationship between trusting beliefs and usage continuance intention: with high privacy restrictiveness, trusting beliefs will have a smaller positive influence on usage continuance intention than with low privacy restrictiveness.

H6): Privacy restrictiveness will moderate the relationship between habit and usage continuance intention: with high privacy restrictiveness, habit will have a larger positive influence on usage continuance intention than with low privacy restrictiveness.

H7): Site experience will moderate the relationship between trusting beliefs and usage continuance intention: with high site experience trusting beliefs will have a smaller positive influence on usage continuance intention than with low site experience.

H8): Site experience will moderate the relationship between habit and usage continuance intention: with high site experience, habit will have a larger positive influence on usage continuance intention than with low site experience.

Fig. 1 shows the model by Lankton et al. [14]. The current research revises the former model by Lankton et al. [14], tests their hypotheses, and generalizes the scope of study outside the U.S. This research proposes a variation on the measurement instrument for privacy restrictiveness and site experience. These concepts contribute to explain continuance intention in the use of SNW.

In this model, dependent variable is usage continuance intention. Independent variables are habits, trusting beliefs, attitude toward using SNW and subjective norm. Two moderator variables are privacy restrictiveness and site experience.

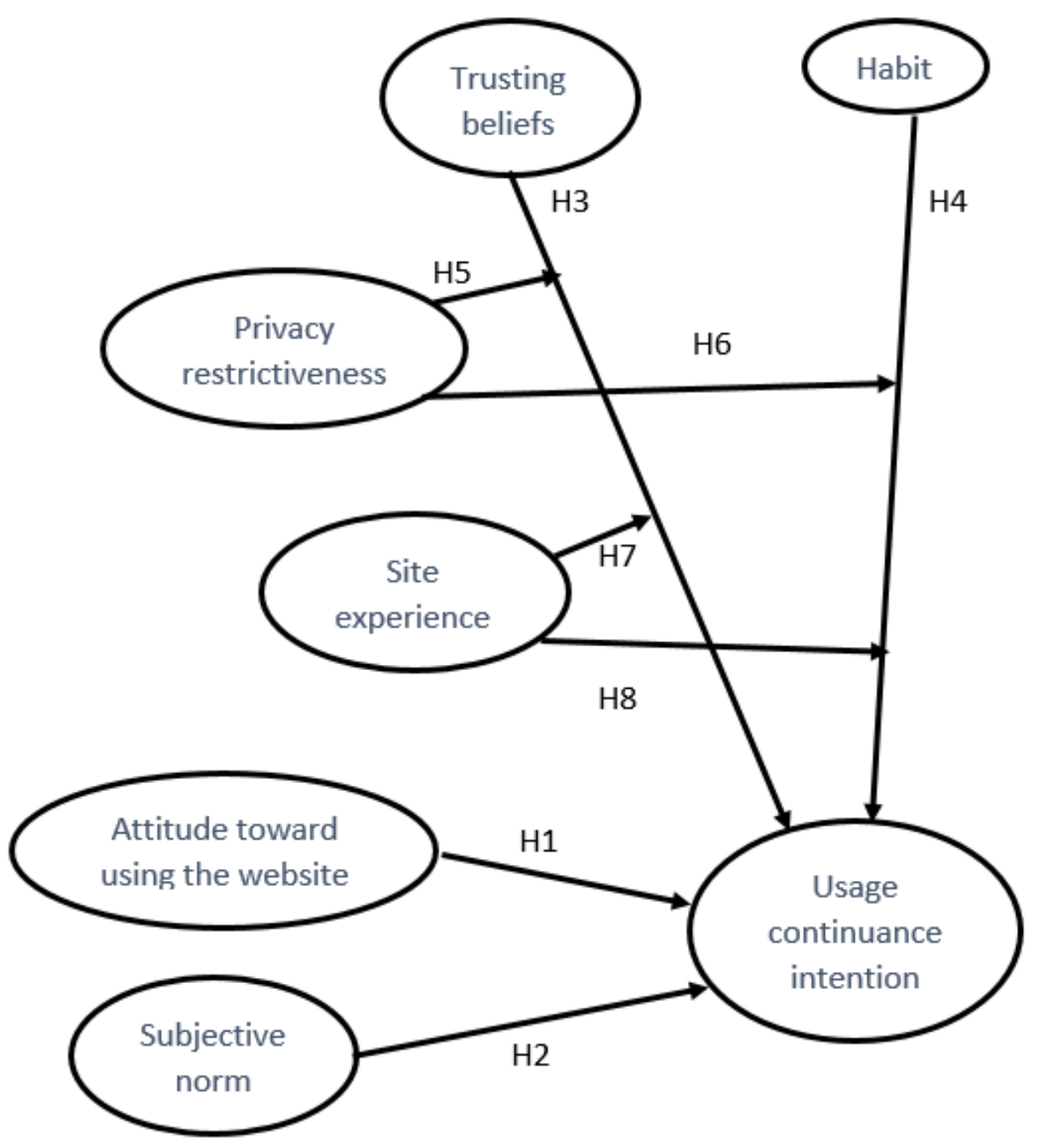

Fig. 1. Research model, as in Lnkton et al. [14].

$17^{\text {th }}$ LACCEI International Multi-Conference for Engineering, Education, and Technology: "Industry, Innovation, And Infrastructure for Sustainable Cities and Communities", 24-26 July 2019, Jamaica. 


\section{MATERIALS AND METHODS}

\section{A. The survey formulary}

The first item in the survey asked about the most frequently used SNW, which would be described by the rest of the items. In this research, answers related to all SNW were processed. Although Facebook is the most used SNW [26], [27], surveyed students were given the opportunity to mention the SNW they use. The reason is that other SNW models will also behave under the influence of usage continuance intention. To refer to the SNW, the survey used the general name MiReDo which comes from the Spanish-English phrase Mi ReD Online (My network online). The factors studied by this research were referred to as FaMiReDo (Factores de Mi ReD Online, or Factors of my network online).

The model by Lankton et al. [14] included site experience and privacy restrictiveness to show they moderate the effects of trusting beliefs and habit on SNW continuance intention. In the measurement instrument used in this research, the items to measure site experience and privacy restrictiveness were expanded.

Lankton et al. [14] measured site experience using length and frequency of prior use. A comparison of methods showed that Sensis [28] measured frequency as the number of times per week that a user enters his SNW, and Chaffey [29] defined engagement as average days accessed monthly. Site experience in this research accounted for time of use, or the time that had passed since the user first used the SNW.

This research enhanced the item about privacy restrictiveness, breaking it down into details of: data is public or private, blocking of users, list creation for followers, control of tagged photos and control of comments. Facebook allows the setting of these details. Table I shows the items proposed.

The construct Friends' usage was measured with three items. Table I shows the items proposed.

To test the changes in the survey, the research team ran the survey in a private university in summer 2018. The feedback obtained from the students gave a second version of the survey. Formats were improved for understandability and one question was dropped out. This new version of the survey omitted one item from [14]: "MiReDo is knowledgeable about online social networking."

TABLE I

ITEMS INCLUDED IN THE SURVEY TO MEASURE FRIENDS' USAGE, SITE EXPERIENCE AND PRIVACY RESTRICTIVENESS

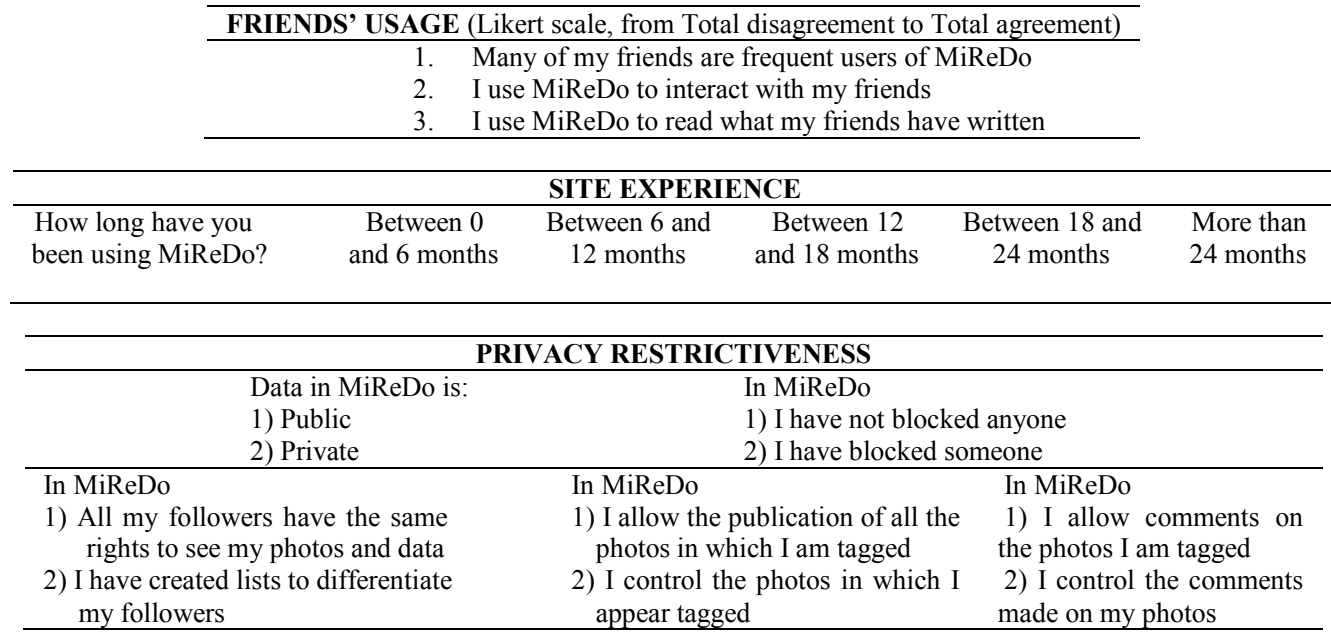

\section{B. $\quad$ The survey data collected}

In the fall and spring semesters 2018, the research team ran the survey again. They told the students that the survey was anonymous and voluntary. There were no items about personal identification, and the statistical process would treat all answers as a single sample, not individually. Students from three universities, one public and two private universities, filled in the survey. In the fall semester 2019 more students were surveyed, and another public university was added to the sample. The final sample size was 222 students, from two public and two private universities.

The distribution of online social networks MiReDo was 185 for Facebook (83.3 \%), 21 for

$17^{\text {th }}$ LACCEI International Multi-Conference for Engineering, Education, and Technology: "Industry, Innovation, And Infrastructure for Sustainable Cities and Communities", 24-26 July 2019, Jamaica. 
Instagram $(9.46 \%)$, nine for Whatsapp (4.05\%), four for Twitter $(1.8 \%)$ and three for other answers (1.35\%). Although Facebook was mentioned in $83.3 \%$ of the cases, all answers were used, since the evaluation did not depend on the SNW used. Average age was 22.3 years. Male participants were 157 students $(70.7 \%)$, and female participants were 60 students $(27.0 \%)$; five students did not give an answer for gender.

Next, internal consistency was measured with Cronbach's alpha, to show close relationship among the items in each construct. Cronbach's alpha for all constructs was higher than 0.7 , as shown in appendix I.

The next step was to perform validity analysis for data, following [30], [31], who studied structural and content validity when developing their instrument. Convergent validity was evaluated using factor analysis. Kaiser - Meyer Olkin test had a high value of 0.894, and Barlett's sphericity test had a high significance $(\mathrm{p}<0.001)$. These two values suggested that data were suitable for analysis. The twelve factors found explained 56.45 percent of accumulated variance. Data did not show normality, according to a Kolmogorov - Smirnov test, and therefore the extraction method was principal axis factorization, and the rotation method was Promax with Kaiser normalization for factor analysis.

A factorial analysis produced a rotated component matrix showing the factors that had closer relationship to the items; all variables differed from each other, achieving thus discriminant validity. Appendix I shows the factor loadings for each item related to its construct. All factor loadings were greater than 0.6. Average variance extracted (AVE) and composite reliability (CR) were also calculated for each construct. All AVE values were greater than 0.57, and all CR values were greater than 0.83 .

\section{RESULTS}

\section{A. $\quad$ Testing hypotheses $\mathrm{H1}$ to $\mathrm{H} 4$}

The model proposed the relationships between the variables with hypotheses $\mathrm{H} 1$ to $\mathrm{H} 4$. Correlation coefficients greater than or equal to 0.5 were accepted. Table II shows the values. The results supported hypotheses H1, H3 and H4 through the correlation matrix. Attitude toward using SNW, trusting beliefs and habit have a positive influence on usage continuance intention. The results did not support hypothesis H2. Subjective norm does not influence usage continuance intention.

TABLE II

CORRELATION TABLE

\begin{tabular}{|c|c|c|c|c|c|}
\hline & Intention & Habit & Beliefs & S. Norm & Attitude \\
\hline $\begin{array}{l}\text { Usage continuance } \\
\text { intention }\end{array}$ & 1 & $0.539(\mathrm{H} 4)$ & $0.561(\mathrm{H} 3)$ & $0.389(\mathrm{H} 2)$ & $0.637(\mathrm{H} 1)$ \\
\hline Habit & & 1 & 0.491 & 0.307 & 0.504 \\
\hline Trusting beliefs & & & 1 & 0.449 & 0.598 \\
\hline Subjective norm & & & & 1 & 0.401 \\
\hline Attitude toward using SNW & & & & & 1 \\
\hline
\end{tabular}

$\mathrm{p}<0.001$ for all values

\section{B. $\quad$ Testing hypotheses H5 and H6}

The test for hypotheses H5 and H6 split data into two parts, considering a median of 8 points for privacy restrictiveness. LOW privacy restrictiveness considered values less than 8 , and HIGH privacy restrictiveness considered values equal to or greater than 8 , according to table III. The relationship between trusting beliefs and usage continuance intention, with high privacy restrictiveness was larger than with low privacy restrictiveness, and therefore hypothesis H5 was not supported. The relationship between habit and usage continuance intention, with high privacy restrictiveness was larger than with low privacy restrictiveness, and therefore hypothesis H6 was supported.

TABLE III

CORRELATION OF USAGE CONTINUANCE INTENTION WITH OTHER CONSTRUCTS

\begin{tabular}{l|ccc|ccc}
\hline \multirow{2}{*}{$\begin{array}{l}\text { Correlation of usage } \\
\text { continuance } \\
\text { intention with: }\end{array}$} & \multicolumn{3}{|c|}{$\begin{array}{c}\text { Moderator: Privacy restrictiveness } \\
\text { Median: 8 }\end{array}$} & \multicolumn{3}{c}{$\begin{array}{c}\text { Moderator: Site experience } \\
\text { Median: 24 months }\end{array}$} \\
\cline { 2 - 8 } & Low & High & $\begin{array}{l}\text { Hypothesis } \\
\text { supported? }\end{array}$ & Low & High & $\begin{array}{c}\text { Hypothesis } \\
\text { supported? }\end{array}$ \\
\hline Trusting beliefs & 0.481 & 0.612 & H5 NO (a) & 0.714 & 0.545 & H7 YES (a) \\
Habit & 0.522 & 0.552 & H6 YES (a) & 0.744 & 0.521 & H8 NO (a) \\
\hline \multicolumn{2}{c}{$p<0.001$ for all values. (a) Same result as in Lankton et al. [14] }
\end{tabular}

$17^{\text {th }}$ LACCEI International Multi-Conference for Engineering, Education, and Technology: "Industry, Innovation, And Infrastructure for Sustainable Cities and Communities”, 24-26 July 2019, Jamaica. 
C.

Testing hypotheses $H 7$ and $H 8$

The test for hypotheses $\mathrm{H} 7$ and $\mathrm{H} 8$ split data into two parts, considering a median of 24 months for site experience. LOW site experience considered values less than 24 months, and HIGH site experience considered values equal to or greater than 24 months, according to table III. The relationship between trusting beliefs and usage continuance intention, with high site experience was smaller than with low site experience, and therefore hypothesis $\mathrm{H} 7$ was supported. The relationship between habit and usage continuance intention, with high site experience was smaller than with low site experience, and therefore hypothesis H8 was not supported.

Based on the supported hypotheses, the resulting model is shown in fig. 2 .

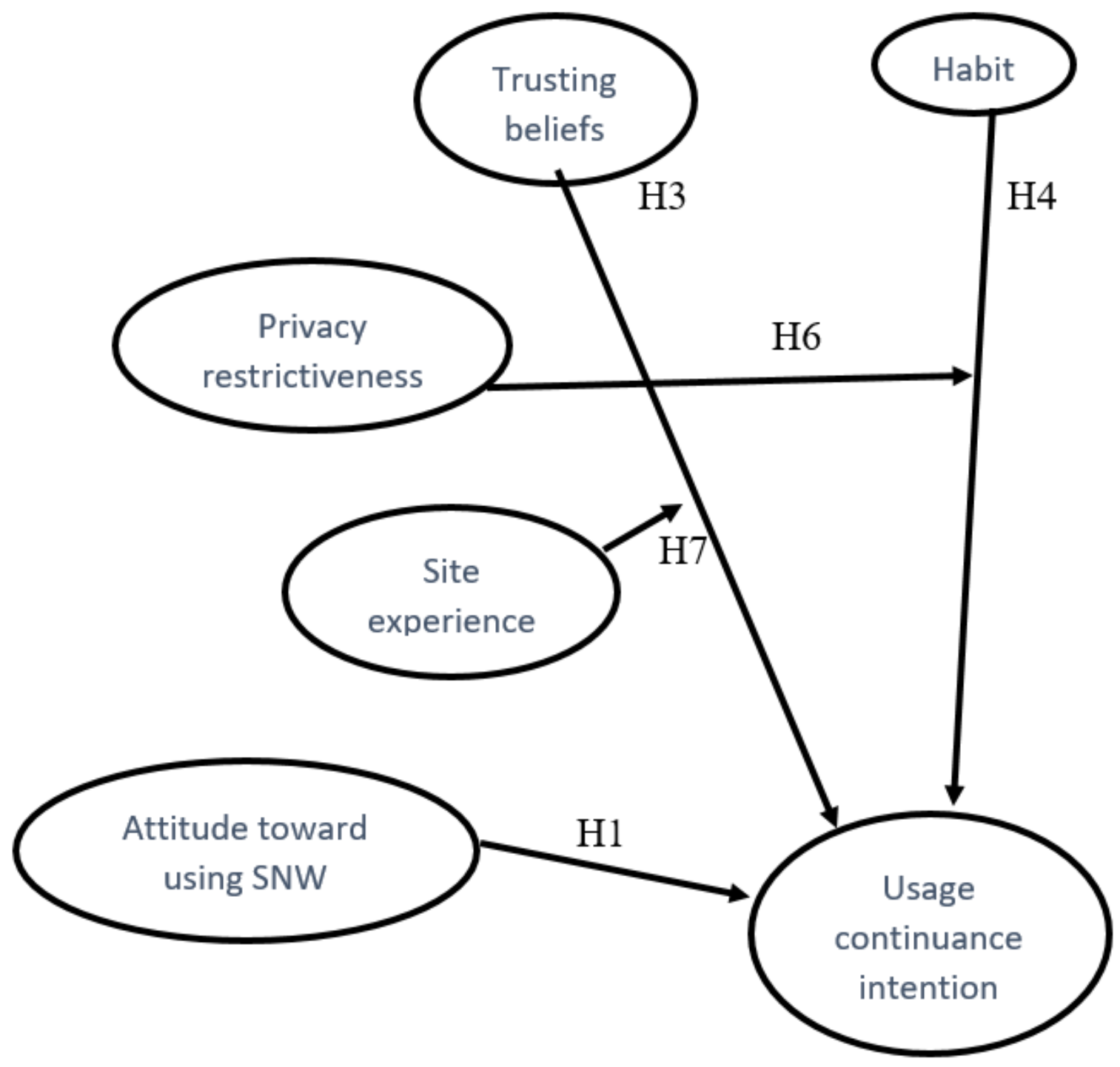

Fig. 2. Resulting model.

\section{DISCUSSION}

\section{A. About this research}

This research studies the relationships of habit and trusting beliefs with usage continuance intention of social networks. Moderators of these relationships are privacy restrictiveness and site experience. Lankton et al. [14] proposed the model used, based on the theory of reasoned action. These authors suggest the possibility of further research. The purpose of this current research is to extend the results of Lankton et al. [14], according to their recommendations. Therefore, this research used a sample of university students outside the U.S. and focused

$17^{\text {th }}$ LACCEI International Multi-Conference for Engineering, Education, and Technology: "Industry, Innovation, And Infrastructure for Sustainable Cities and Communities”, 24-26 July 2019, Jamaica. 
on students of private and public universities in Perú.

Three items, two items more than the original survey, measured the construct use by my friends; the Cronbach's alpha value confirmed the internal consistency between the three items used. The construct site experience was measured in months of use. Five items, four items more than the original research, measured the construct privacy restrictiveness. Privacy restrictiveness was the sum of the item values.

Based on the proposed model, a correlation matrix showed the relationship between the constructs usage continuance intention, attitude toward using SNW, subjective norm, trusting beliefs and habit. Correlation values greater than 0.5 confirmed relationships between variables. The correlation matrix supported hypotheses H1, $\mathrm{H} 3$ and $\mathrm{H} 4$ confirming the following relationships: Attitude toward using SNW, trusting beliefs and habit will have a positive influence on usage continuance intention. Hypothesis $\mathrm{H} 2$ did not show influence of subjective norm on usage continuance intention. The results for these four hypotheses, confirm the results from Lankton et al. [14]. Therefore, the new condition of students from universities outside the U.S. shows that the relationships are valid in these two different countries: U.S. and Perú.

The test for hypotheses H5 and H6, measured the construct privacy restrictiveness adding five items: 1) Data in the SNW is public or private, 2) all followers have the same rights to see photos and data, or lists differentiate followers, 3) the user allows publication or controls the photos in which he is tagged, 4) the user allows comments on the photos he appears or not, and 5) the user has blocked someone or not. The resulting privacy restrictiveness ranged from 1 to 10 , with a median value of 8 . The test split data into two parts, using the median value of privacy restrictiveness: low privacy restrictiveness for values less than 8 and high privacy restrictiveness for values greater than or equal to 8 . It was expected that the correlation between trusting beliefs and usage continuance intention would be smaller for the subset with high privacy restrictiveness; however, this was not the result. Therefore, hypothesis H5 was not supported with the data obtained in this research. There was no evidence to show that privacy restrictiveness would moderate the relationship between trusting beliefs and usage continuance intention. Also, it was expected that the correlation between habit and usage continuance intention would be larger for the subset with high privacy restrictiveness; and this was the result. Therefore, hypothesis H6 was supported with the data obtained in this research. There was evidence to show that privacy restrictiveness would moderate the relationship between habit and usage continuance intention.

To test hypotheses $\mathrm{H} 7$ and $\mathrm{H} 8$, the construct site experience asked how long the user had used the SNW; the resulting site experience ranged from 0 to 24 months, with a median value of 24 months. The test split data into two parts, using the median value of site experience: low site experience for values less than 24 months and high site experience for values greater than or equal to 24 months. It was expected that the correlation between trusting beliefs and usage continuance intention would be larger for the subset with low site experience, and this was the result. Therefore, hypothesis H7 was supported, showing that site experience would moderate the relationship between trusting beliefs and usage continuance intention. Also, it was expected that the correlation between habit and usage continuance intention would be larger for the subset with high site experience, but this was not the result. Therefore, hypothesis $\mathrm{H} 8$ was not supported. There was no evidence to show that site experience would moderate the relationship between habit and usage continuance intention.

\section{B. $\quad$ Further research}

Since the study limits the use of SNW to university environments, two further researches may continue. First, knowing the behavior of SNW users, university management may reach students through SNW, for academic and administrative purposes, and for improving loyalty in the students [32]-[42]. Second, the research can be extended to other environments, for example tourism, health, retail, among others.

\section{Managerial relevance}

Information technology supports SNW. This research has studied SNW, taking information technology for granted. However, progress in information technology must be followed close together to progress in SNW, to make proposals for new functionalities. Universities have been a good field of measurement for factors related to SNW; universities concentrate young people as well as experienced people, academic research as well as administrative work. Lessons learned at the university environment can be easily applied to other business environments. The results show that trusting beliefs and habit improve continuance usage intention of social networks,

$17^{\text {th }}$ LACCEI International Multi-Conference for Engineering, Education, and Technology: "Industry, Innovation, And Infrastructure for Sustainable Cities and Communities”, 24-26 July 2019, Jamaica. 
and that site experience and privacy restrictiveness moderate these two previous relationships.

\section{CONCLUSIONS}

Three variables confirm their influence on usage continuance intention in the social networks: attitude toward using SNW, trusting beliefs and habit. Subjective norm confirms once more that it has no influence on usage continuance intention. Site experience confirms its role as a moderator in the relationship between trusting beliefs and usage continuance intention. Privacy restrictiveness confirms its role as a moderator in the relationship between habit and usage continuance intention. Since the original work, results have been extended from one to two countries, and from public to public and private universities. To improve the use of social networks, work could be done to improve trusting beliefs and habit.

\section{ACKNOWLEDGMENTS}

Universidad Nacional de Ingeniería in Lima, Perú, financed the presentation of this paper to the LACCEI Conference.

\section{REFERENCES}

[1] M. Sánchez-Franco, Á. Villarejo-Ramos, and F. MartínVelicia, "Social integration and post-adoption usage of Social Network Sites. An analysis of effects on learning performance," Procedia Social and Behavioral Sciences, vol. 15, pp. 256-262, 2011.

[2] R. Kaur, and S. Singh, "A survey of data mining and social network analysis based anomaly detection techniques," Egyptian Informatics Journal, vol. 17, pp. 199-216, 2016.

[3] J. Choi, and W. Kang, "A Dynamic Examination of Motives for Using Social Media and Social Media Usage Among undergraduate students: A latent class analysis," Procedia Social and Behavioral Sciences, vol. 131, pp. 202-210, 2014.

[4] J. Viluckiene, "The relationship between online social networking and offline social participation among people with disability in Lithuania," Procedia - Social and Behavioral Sciences, vol. 185, pp. 453-459, 2015.

[5] X. Zheng, Z. Zheng, Z. Chen and C. Rong, "Detecting spammers on social networks," Neurocomputing, vol. 159, pp. 27-34, 2015.

[6] B. Nandhini, and J. Sheeba, "Online Social Network Bullying Detection Using Intelligence Techniques. International Conference on Advanced Computing Technologies and Applications (ICACTA - 2015)," Procedia Computer Science, vol. 45, pp. 485 - 492, 2015.

[7] V. Subramaniyaswamy, R. Logesh, V. Vijayakumar, and V. Indragandhi, "Automated message filtering system in online social network," Procedia Computer Science, vol. 50, pp. 466-475, 2015.

[8] M. Chorley, R. Whitaker and S. Allen, "Personality and location-based social networks," Computers in Human Behavior, vol. 46, pp. 45-56, 2015.

[9] F. Du, J. Zhang, H. Li, J. Yan, S. Galloway and K. Lo, "Modelling the impact of social network on energy savings," Applied Energy, vol. 178, pp. 56-65, 2016.
[10]Z. Du, Y. Liu, and Y. Wang, "Relation Based Access Control in Campus Social Network System," Procedia Computer Science, vol. 17, pp. 14-20, 2013.

[11]K. Howells and A. Ertugan, "Applying fuzzy logic for sentiment analysis of social media network data in marketing. $9^{\text {th }}$ International Conference on Theory and Application of Soft Computing, Computing with Words and Perception, ICSCCW 2017, pp. 24-25, August 2017, Budapest, Hungary.

[12]L. Can and N. Kaya, "Social networking sites addiction and the effect of attitude towards social network advertising, Procedia Social and Behavioral Sciences, vol. 235, pp. $484-492,2016$.

[13] We are social. (March 27 $7^{\text {th }}$, 2018). Digital in 2018 Hootsuite [Online]. Available: https://wearesocial.com/blog/2018/01/global-digitalreport-2018 (accessed on March $27^{\text {th }}, 2018$ ).

[14]N. Lankton, D. McKnight and J. Thatcher, "The moderating effects of privacy restrictiveness and experience on trusting beliefs and habit: an empirical test of intention to continue using a social networking website", IEEE Transactions on Engineering Management, vol. 59, no. 4, pp. 654-665, J. 2012.

[15] J. Balujeva, "EWOM communication in social media: A study of its antecedents in higher education context, Master thesis", Lappeenranta University of Technology, School of Technology, International Marketing Management, Finland.

[16]J. Bowden, "Engaging the student as a customer: A relationship marketing approach," Marketing Education Review, vol. 21, no. 3, pp. 211-228, 2011.

[17]N. Labib and R. Mostafa, "Determinants of Social Networks Usage in Collaborative Learning: Evidence from Egypt," Procedia Computer Science, vol. 65, pp. 432-441, 2015.

[18]W. Al-Ghaith, "Understanding social Network usage: Impact of co-presence, intimacy, and immediacy," International Journal of Advanced Computer Science and Applications, vol. 6, no. 8, pp. 99-110, 2015.

[19]Z. Zhang, "Feeling the sense of community in social networking usage," IEEE Transactions on Engineering Management, vol. 57, no. 2, pp. 225-239, 2010.

[20]I. Ajzen and M. Fishbein, Understanding attitudes and predicting social behavior. Englewood Cliffs, New Jersey: Prentice-Hall, 1980

[21] J. Lee and R. Rao, "A study of customers' trusting beliefs in government-to-consumer online services,". AMCIS 2003 Proceedings. Paper 102, 2003.

[22]W. Wang and I. Benbasat, "Attributions of trust in decision support technologies: A study of recommendation agents for e-commerce," Journal of management information systems, vol. 24, no. 4, pp. 249-273, 2008 .

[23] G. Murphy, "Propensity to trust, purchase experience, and trusting beliefs of unfamiliar e-commerce ventures," New England Journal of Entrepreneurship, vol. 6, no. 2, pp. 53-64, 2003.

[24]D. McKnight, V. Choudhury and C. Kacmar, "The impact of initial consumer trust on intentions to transact with a web site: a trust building model," Journal of strategic information systems, vol. 11, pp. 297-323, 2002.

[25]Y. Chen, S. Chien, J. Wu, and P. Tsai, P. "Impact of Signals and Experience on Trust and Trusting Behavior," Cyberpsychology, Behavior, and Social Networking, vol 13, no. 5, pp. 539-546, 2010.

[26]D. Chaffey, "Digital market trends for 2017," Smart Insights (April 15 ${ }^{\text {th }}$, 2017) [Online]. Available: https://www.smartinsights.com/managing-digitalmarketing/marketing-innovation/digital-marketing-trends2016-2017/ (accessed on September 28, 2018).

$17^{\text {th }}$ LACCEI International Multi-Conference for Engineering, Education, and Technology: "Industry, Innovation, And Infrastructure for Sustainable Cities and Communities”, 24-26 July 2019, Jamaica. 
[27] Statista. (2017). El portal estadístico por excelencia [Online]. Available: https://es.statista.com/ (accessed on September $\left.28^{\text {th }}, 2018\right)$.

[28]Sensis (2017). Social Media Report [Online]. Available: https://www.sensis.com.au/asset/PDFdirectory/Sensis_Soc ial Media Report 2017-Chapter-1.pdf (accessed on March 22 $2^{\text {nd }}, 2017$ ).

[29]D. Chaffey, "Global social media research summary 2016," [Online]. Available: http://c.ymcdn.com/sites/www.productstewardship.us/reso urce/resmgr/Phone Books/Global_Social_Media_Statisti. pdf (accessed on March 22 $\left.2^{\text {nd }}, 2018\right)$.

[30]F. Liñan and Y. Chen, "Development and cross-cultural application of a specific instrument to measure entrepreneurial intentions," Entrepreneurship Theory and Practice, pp. 593-617, May 2009.

[31]Z. Su and H. Yang, "Managerial ties and exploratory innovation: An opportunity - motivation - ability perspective," IEEE Transactions on Engineering Management, vol. 65, no. 2, pp. 227-238, 2018.

[32]Y. Chen, "The impact of marketing strategies and satisfaction on student loyalty: a structural equation model approach," International Education Studies, vol. 9, no. 8; pp. 94-104, 2016.

[33]A. Kunanusorn and D. Puttawong, "The mediating effect of satisfaction on student loyalty to higher education institution," European Scientific Journal, vol. 1, pp. 449463,2015

[34]F. Ahmed, R. Illahe, N. Ahmad, M. Nadeem and K. Rehman, "Impact of student's satisfaction on loyalty. A case of private sector business schools from Punjab Pakistan," Journal of Marketing and Consumer Research, vol. 15, pp. 154-159, 2015.

[35] S. Phadke, "Modeling the determinants of student loyalty in Indian higher education setting," International Conference on Management, Behavioral Sciences and Economics Issues. ICMBSE'2011, pp. 262-264, 2015.

[36] M. Mohamad and Z. Awang, "Building corporate image and securing student loyalty in the Malaysian higher learning industry," The Journal of International Management Studies, vol. 4, no. 1, pp. 30-40, 2009.

[37]E. Nesset and Ø. Helgesen, "Modelling and managing student loyalty: A study of a Norwegian university college," Scandinavian Journal of Educational Research, vol. 53, no. 4, pp. 327-345, 2009

[38]J. Rojas-Méndez, A. Vásquez-Párraga, A., Kara and A. Cerda-Urrutia, "Determinants of student loyalty in higher education: a tested relationship approach in Latin America," Latin American Business Review, vol. 10, no. 1, pp. 21-39, 2009.

[39]R. Brown and T. Mazzarol, "The importance of institutional image to student satisfaction and loyalty within higher education," Springer Science + Business Media B.V. 2008 High Educ., vol. 58, pp. 81-95, 2009.
[40]M. Fuciu and H. Gorski, "Marketing Research regarding the Usage of Online Social Networking Sites by High School Students," Procedia Economics and Finance, vol. 6, pp. 482-490, 2013.

[41]L. Leong and O. Ibrahim, "Role of information system (IS), social networking technology (SNT) and web 2.0 for improving learning outcomes: A case of Malaysian universities," Procedia Social and Behavioral Sciences, vol. 211, pp. 111-118, 2015.

[42] S. Schlattmann, "Capturing the collaboration intensity of research institutions using social network analysis," Procedia Computer Science, vol. 106, pp. 25-31, 2017.

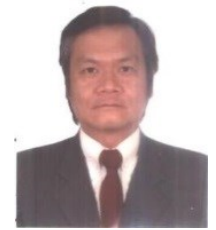

Alberto Un Jan, is engineer in electronics from Universidad Nacional de Ingeniería (UNI) in Lima, Perú. He holds an M.Sc. degree in systems engineering (UNI), M.Sc. degree in information and systems in management from Sheffield City Polytechnic, UK, and a Doctor degree in engineering from Universidad Nacional Federico Villarreal, Lima, Perú. He has done research at Karl Franzens Universität, Graz, Austria, and University of Ljubljana, Slovenia. His research interest is in information systems and dynamic simulation.

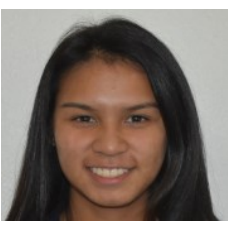

Vilma Un Jan, is B.S. in software engineering from Florida Gulf Coast University, USA. Her research interest is in machine learning and data mining.

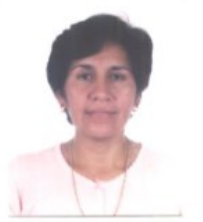

Vilma Contreras, is B.S. in systems engineering from Universidad Nacional de Ingeniería in Lima, Perú, she has studied for the M.Sc. degree in applied statistics at

Universidad Nacional Agraria La Molina, Lima, Perú. Her research interest is in statistical models.

$17^{\text {th }}$ LACCEI International Multi-Conference for Engineering, Education, and Technology: "Industry, Innovation, And Infrastructure for Sustainable Cities and Communities”, 24-26 July 2019, Jamaica. 


\section{APPENDIX I}

\begin{tabular}{|c|c|c|c|c|}
\hline Item & $\begin{array}{c}\text { Cronbach's } \\
\alpha\end{array}$ & $\begin{array}{l}\text { Factor } \\
\text { loading }\end{array}$ & AVE & $\begin{array}{l}\text { Composite } \\
\text { reliability }\end{array}$ \\
\hline $\begin{array}{l}\text { L011 } \\
\text { L012 } \\
\text { L013 }\end{array}$ & $\begin{array}{c}\text { Usage } \\
\text { continuance } \\
\text { intention } \\
0.895 \\
\end{array}$ & $\begin{array}{l}0.858 \\
0.897 \\
0.902\end{array}$ & 0.784 & 0.916 \\
\hline $\begin{array}{l}\text { L021 } \\
\text { L022 } \\
\text { L023 }\end{array}$ & 0.885 & $\begin{array}{l}0.856 \\
0.907 \\
0.883\end{array}$ & 0.778 & 0.913 \\
\hline $\begin{array}{l}\text { L031 } \\
\text { L032 } \\
\text { L033 } \\
\text { L034 }\end{array}$ & $\begin{array}{l}\text { Trusting } \\
\text { belief - } \\
\text { Integrity } \\
0.919\end{array}$ & $\begin{array}{l}0.844 \\
0.887 \\
0.879 \\
0.895 \\
\end{array}$ & 0.768 & 0.930 \\
\hline $\begin{array}{l}\text { L041 } \\
\text { L042 } \\
\text { L043 }\end{array}$ & $\begin{array}{c}\text { Trusting } \\
\text { belief - } \\
\text { Competence } \\
0.911\end{array}$ & $\begin{array}{l}0.885 \\
0.929 \\
0.911\end{array}$ & 0.825 & 0.934 \\
\hline $\begin{array}{l}\text { L051 } \\
\text { L052 } \\
\text { L053 }\end{array}$ & $\begin{array}{c}\text { Trusting } \\
\text { belief - } \\
\text { Benevolence } \\
0.826\end{array}$ & $\begin{array}{l}0.614 \\
0.885 \\
0.878\end{array}$ & 0.643 & 0.841 \\
\hline $\begin{array}{l}\text { L061 } \\
\text { L062 } \\
\text { L063 } \\
\text { L064 }\end{array}$ & $\begin{array}{c}\text { Technology } \\
\text { trusting } \\
\text { belief - } \\
\text { Reliability } \\
0.798\end{array}$ & $\begin{array}{l}0.830 \\
0.668 \\
0.766 \\
0.764\end{array}$ & 0.576 & 0.844 \\
\hline
\end{tabular}

\begin{tabular}{|c|c|c|c|c|}
\hline Item & $\begin{array}{c}\text { Cronbach's } \\
\alpha \\
\end{array}$ & $\begin{array}{l}\text { Factor } \\
\text { loading }\end{array}$ & AVE & $\begin{array}{c}\text { Composite } \\
\text { reliability }\end{array}$ \\
\hline $\begin{array}{l}\mathrm{L} 071 \\
\mathrm{~L} 072 \\
\mathrm{~L} 073 \\
\mathrm{~L} 074\end{array}$ & $\begin{array}{l}\text { Technology } \\
\text { trusting } \\
\text { belief - } \\
\text { Functionality } \\
0.801\end{array}$ & $\begin{array}{l}0.807 \\
0.810 \\
0.787 \\
0.701\end{array}$ & 0.605 & 0.859 \\
\hline $\begin{array}{l}\text { L081 } \\
\text { L082 } \\
\text { L083 } \\
\text { L084 }\end{array}$ & $\begin{array}{c}\text { Technology } \\
\text { trusting } \\
\text { belief- } \\
\text { Helpfulness } \\
0.866\end{array}$ & $\begin{array}{l}0.840 \\
0.886 \\
0.844 \\
0.695\end{array}$ & 0.671 & 0.890 \\
\hline $\begin{array}{l}\text { L091 } \\
\text { L092 } \\
\text { L093 } \\
\end{array}$ & $\begin{array}{c}\text { Subjective } \\
\text { norm } \\
0.919 \\
\end{array}$ & $\begin{array}{l}0.884 \\
0.915 \\
0.871 \\
\end{array}$ & 0.792 & 0.919 \\
\hline $\begin{array}{l}\text { L101 } \\
\text { L102 } \\
\text { L103 }\end{array}$ & $\begin{array}{c}\text { Attitude } \\
\text { toward using } \\
\text { SNW } \\
0.873 \\
\end{array}$ & $\begin{array}{l}0.724 \\
0.815 \\
0.820\end{array}$ & 0.620 & 0.830 \\
\hline $\begin{array}{l}\text { L111 } \\
\text { L1 1 } \\
\text { L113 } \\
\text { L114 } \\
\end{array}$ & $\begin{array}{c}\text { Perceived } \\
\text { usefulness } \\
0.903\end{array}$ & $\begin{array}{l}0.843 \\
0.872 \\
0.816 \\
0.790 \\
\end{array}$ & 0.690 & 0.899 \\
\hline $\begin{array}{l}\text { L121 } \\
\text { L122 } \\
\text { L123 } \\
\end{array}$ & $\begin{array}{c}\text { Friend's } \\
\text { usage } \\
0.712 \\
\end{array}$ & $\begin{array}{l}0.842 \\
0.835 \\
0.764 \\
\end{array}$ & 0.663 & 0.855 \\
\hline
\end{tabular}

$17^{\text {th }}$ LACCEI International Multi-Conference for Engineering, Education, and Technology: "Industry, Innovation, And Infrastructure for Sustainable Cities and Communities", 24-26 July 2019, Jamaica. 